\title{
Stability study of Laghusutashekhara Rasa Tablets - With Respect to Baseline Microbial Diagnostic Modalities
}

\author{
Research Article
}

\author{
Ashvinee Vasava ${ }^{1}$, Meera Cholera ${ }^{2}$, Shubhangi Kamble ${ }^{3 *}$ \\ 1. PG scholar, Department of Basic Principles, IPGT \& RA, Jamnagar. \\ 2. Head, Microbiology Laboratory, IPGT \& RA, Jamnagar. \\ 3. Associate Professor, Department of Basic Principles, IPGT \& RA, Jamnagar.
}

\begin{abstract}
Background: In last a few decades, market of herbal, herbo-mineral and traditional medicines have grown up leap and bound. The main drawback of traditional medicines is lack of stability. Hence the present study was carried out to observe the stability of Laghusutashekhara Rasa tablet with respect to its stability against microbial contamination of sample prepared and stored in different climatic conditions and temperature. Aim: To study the stability of Laghusutashekhara Rasa tablet and to check microbial contamination in the finished product at different time intervals, at different climatic conditions, temperature and humidity set ups. Materials and Methods: Sample of Laghusutashekhara Rasa tablet was studied to check microbial contamination at different climatic conditions. The study was conducted at Microbiology Laboratory, IPGT \& RA, Jamnagar, Gujarat, India. Observations \& Results: The initial microbiological study was done to rule out stability of prepared drug up to first consumption of the same. The study of Laghusutashekhara Rasa tablet was done on $3^{\text {rd }}$ day of preparation, before giving to the patients i.e. first day of drug consumption after preparation of drug. Then further study was carried out at regular time intervals up to 220 days. Conclusion: In microbiological study of Laghusutashekhara Rasa tablet, growth of micro-organisms (bacterial or fungal) was not found till $10^{\text {th }}$ February, 2020 from the date of preparation, which shows its stability and good shelf life. Hence in present study the stability test of Laghusutashekhara Rasa tablet with respect to microbiological findings was negative at room temperature, warm and cold, dry and humid conditions.
\end{abstract}

Key Words: Stability, Microbial profile, Laghusutashekhara Rasa, Climatic conditions.

\section{Introduction}

Stability research provides proof of how the quality of a drug substance or product changes over time, affected by a number of environmental factors such as temperature, humidity and light, as well as determining substitution duration for the drug substance or product and prescribed storage. So we can say stability study is necessary as an assessment of product quality (1). The main purpose of pharmaceutical stability testing is to provide fair assurance that the drugs will remain at an appropriate standard of fitness/ quality during the time of which they are available to patients in the market and will be suitable for their use before the patient uses the final product unit (2). Ayurvedic Indian Formulary has also provided the time from the date of manufacture during which the formulations should be consumed for better results. In various literatures of ayurveda, the word "Saviryata Avadhi" is stated in the sense of the time during which any drug's Virya (potency) remains unaffected due to environmental/microbial degradation (3).There are two

* Corresponding Author:

\section{Shubhangi Kamble}

Associate Professor,

Department of Basic Principles,

IPGT \& RA, Jamnagar, Gujarat, India

Email Id: drshubhashre@gmail.com types of stability study; one is accelerated stability and second is real time stability. Tablet preparations are widely and largely used in pharmacy as well as by the practitioners of Ayurveda for different ailments. According to Ayurvedic Pharmaceutical Science, Vati preparations remain potent up to 1 year (4) (5), after which they start degrading gradually, thus losing their efficacy. In present study, the drug was prepared in Pharmacy of Gujarat Ayurved University, Jamnagar. No any preservative was added to the test drug. Drug preparation was finished on 2nd July, 2019. Finished product was stored in airtight plastic container at room temperature. In the present study an attempt was carried out to check stability of tablet with respect to its microbial profile at different climatic conditions and temperature setups at regular intervals for a period of 220 days.

\section{Aim}

To study the stability of finished product of Laghusutashekhara Rasa tablet and to check microbial contamination in the finished product at different time intervals - at different climatic conditions, temperature and humidity set ups.

\section{Materials and Methods}

Sample of Laghusutashekhara Rasa tablet was studied to check microbial contamination at different 
climatic conditions. The study was conducted at Microbiology Laboratory, IPGT \& RA, Jamnagar, Gujarat.

Mainly two tests were performed to rule out the existence of any bacteria or fungi in the prepared drug as a finished product.

The initial microbiological study was done on $3^{\text {rd }}$ day of preparation, before giving drug to the patients. Then samples from same container were subjected to the microbiological study regularly with random intervals during different seasons.

\section{Drug materials}

One herbal raw drug Shunthi was obtained from Pharmacy of Gujarat Ayurved University, Jamnagar and other ingredient was collected from local market of Jamnagar. The ingredients and the part used are given in (Table 1).

Table 1: Ingredients of Laghusutashekhara Rasa tablet

\begin{tabular}{|r|c|c|c|c|}
\hline $\begin{array}{c}\text { Sr. } \\
\text { No. }\end{array}$ & $\begin{array}{c}\text { Name of } \\
\text { Ingredient }\end{array}$ & $\begin{array}{c}\text { Latin/ } \\
\text { English } \\
\text { name }\end{array}$ & $\begin{array}{c}\text { Part } \\
\text { used }\end{array}$ & $\begin{array}{c}\text { Proporti } \\
\text { on }\end{array}$ \\
\hline 1 & $\begin{array}{c}\text { Shuddha } \\
\text { Suvarna } \\
\text { Gairika }\end{array}$ & $\begin{array}{c}\text { Ferric oxide } \\
\text { red }\end{array}$ & - & 1 part \\
\hline 2 & Shunthi & $\begin{array}{c}\text { Zingiber } \\
\text { officinale } \\
\text { Roscoe. }\end{array}$ & $\begin{array}{c}\text { Dried } \\
\text { Rhizome }\end{array}$ & 1 part \\
\hline
\end{tabular}

\section{Preparation Time:}

The drug Laghusutashekhara Rasa tablet was prepared by following Standard Operating Procedure (SOP) with the utmost care to avoid any sort of contamination in Pharmacy, Gujarat Ayurved University, Jamnagar.

\section{Date of preparation: 02.07.2019 Storage}

Laghusutashekhara Rasa tablets were stored in plastic containers at room temperature in a cool, dark and dry place. Samples were subjected to stability study with respect to microbial and fungal contamination at regular time intervals. Details of which are cited below-

\section{Microbial Profile}

Microbial contamination was assessed by two methods to check any mycological findings and bacteriological findings.

\section{Smear Examination}

A.Wet mount $/ 10 \% \mathrm{KOH}$ Preparation

B.Gram's stain

\section{Culture Study}

\section{C.Fungal culture}

D.Aerobic culture

The details of the procedures followed are given below-

\section{Smear Examination}

A. Wet mount $/ 10 \% \mathrm{KOH}$ Preparation

Aim: To rule out any mycological findings.

Specimen: Laghusutashekhara Rasa tablet

\section{Procedure for Wet Preparation}

Take a clean grease free glass slide. Put the selected material. Add some distilled water (as per need). Then cover it with grease free cover glass. Observe under the high power $(40 x)$ lens. Note the findings.

\section{Procedure for $10 \% \mathrm{KOH}$ Preparation}

Mix Potassium Hydroxides pellets in distilled water to prepare $10 \%$ of the same in clean glass tube. Take a clean grease free glass slide. Put a drop of specimen and add freshly prepared $10 \% \mathrm{KOH}$ then cover with grease free cover glass. Allow it to react for 15-20 minutes to remove extra debris other than fungal particles. Observe under high power $(40 x)$ lens. Note the findings.

\section{Gram's stain test}

Gram staining is a differential staining technique that differentiates bacteria into two groups: Gram positive and Gram negative. The procedure is based on the ability of microorganisms to retain colour of the stains used during the gram stain procedure. Gram negative bacteria are decolorized by any organic solvent (acetone or Gram's decolourizer) while Gram positive bacteria are not decolorized as primary dye retained by the cell and bacteria will remain as purple. After decolonization step, a counter stain effect found on Gram negative bacteria and bacteria will remain pink. The Gram stain procedure enables bacteria to retain colour of the stains, based on the differences in the chemical and physical properties of the cell wall. (Alfred E Brown, 2001)

Aim: To rule out any bacteriological findings.

Specimen: Laghusutashekhara Rasa tablet

\section{Procedure for Gram's Stain}

Take clean grease free glass slide to prepare a Smear. Fix the prepared smear by passing 3-4 times over the flame of Bunsen burner, then cover the smear with Gram's crystal violet solution and allow to remain for mentioned time as per kit procedure. Wash off smear to remove excessive reagent with tap water. Cover smear with Gram's Iodine solution and allow to remain for mentioned time as per kit procedure. Wash off smear to remove excessive reagent with tap water. Decolorize smear with Gram's decolorizer by holding the slide at slope. Wash off smear to remove excess acetone with tap water. Cover smear with Safranin solution and allow to remain for mentioned time as per kit procedure. Wash off smear to remove excessive reagent with tap water. Blot and allow to dry smear. Examine under oil immersion lens and report as per findings $(5,6)$.

\section{Culture Study}

The materials collected with sterile cotton swab for inoculation purpose on selected fungal culture media (i.e. an artificial preparation). 
Name of media:

Company :

Required time duration:

Required temperature:

Use of media :

Sabouraud Dextrose Agar Base (SDA),

Modified (Dextrose Agar Base, Emmons)

HIMEDIA Laboratories Pvt. Ltd.

05 to 07 days

\section{$37{ }^{\circ} \mathrm{C}$}

For selective cultivation of pathogenic fungi.

\section{Procedure for Fungal Culture}

For inoculation purposes choose the correct selective solid media.

Selective solid media dry in a hot air oven until inoculation of the specimen.

Sterile cotton swab or Nichrome wire (24 S.W.G. size) loop to inoculate specific specimen.

After the inoculation cycle, incubate the inoculated medium in an inverted position at 370c for 05 to 07 to 21 days in incubator (incubation days are as per growth requirement) in an aerobic atmosphere (7).

After selected incubation period, examine growth by naked eye in form of colony or aerial growth and confirmed growth by performing different related biochemical reactions and different related staining procedures.

\section{B. Aerobic culture method:}

Respected materials collected with sterile cotton swab for inoculation purpose on selected aerobic culture media (i.e. an artificial preparation)
Name of media:

Company :

Required time duration : 24 to 48 hours

Required temperature:

Use of media :

\section{Procedure for Aerobic Culture}

Choose appropriate selective solid media for inoculation purpose. Dry selective solid media in hot air oven before specimen inoculation. Inoculate selected specimen by four flame method on surface of cool dried medium with nichrome wire (24 S.W.G. size) loop. After streaking process incubate inoculated medium in inverted position at 370c for 18-24 hours in incubator under aerobic or $10 \% \mathrm{CO} 2$ atmosphere. After selected incubation period examine growth by naked eye in form of colony and confirm growth by performing different related biochemical reactions and different related staining procedures after that report isolates (8).

\section{Observations \& Results}

The initial microbiological study of Laghusutashekhara Rasa tablet was done on $3^{\text {rd }}$ day of preparation, before giving to the patients i.e. $1^{\text {st }}$ day of drug consumption after preparation of drug to rule out stability of prepared drug up to consumption of the same.. Then further study was carried out at regular time intervals up to 220 days i.e. last day of consumption. Observations and results of the study with humidity and temperature are depicted in table no. 2 .

Table 02: Showing observations of Laghusutashekhara Rasa Tablet (Drug Preparation Date: 02.07.2019)

\begin{tabular}{|c|c|c|c|c|c|c|c|}
\hline \multirow[b]{2}{*}{ Sr. No. } & \multirow{2}{*}{$\begin{array}{l}\text { Days of } \\
\text { Study at }\end{array}$} & \multirow{2}{*}{$\begin{array}{c}\text { Date of } \\
\text { Sample given }\end{array}$} & \multirow{2}{*}{$\begin{array}{c}\text { Temp. } \\
\left({ }^{0} \mathrm{C}\right) \\
\text { \& Humidity }\end{array}$} & \multicolumn{4}{|c|}{ Observations/Findings } \\
\hline & & & & $\begin{array}{c}\text { Gram's } \\
\text { Stain }\end{array}$ & $\begin{array}{l}\text { Aerobic } \\
\text { culture }\end{array}$ & $\begin{array}{l}\text { Wet mount/ } 10 \% \\
\text { KOH Preparation }\end{array}$ & Fungal culture \\
\hline 1 & 3 Days & 05/07/2019 & $\begin{array}{l}30^{0} \mathrm{C} \\
72 \%\end{array}$ & $\begin{array}{c}\text { Microorganisms } \\
\text { Not Seen }\end{array}$ & $\begin{array}{l}\text { No organisms } \\
\text { isolated }\end{array}$ & $\begin{array}{l}\text { Fungal filaments } \\
\text { not seen. }\end{array}$ & $\begin{array}{c}\text { No Fungal } \\
\text { Pathogen Isolated }\end{array}$ \\
\hline 2 & 66 Days & 09/09/2019 & $\begin{array}{l}28^{0} \mathrm{C} \\
86 \%\end{array}$ & $\begin{array}{c}\text { Microorganisms } \\
\text { Not Seen }\end{array}$ & $\begin{array}{l}\text { No organisms } \\
\text { isolated }\end{array}$ & $\begin{array}{c}\text { Fungal filaments } \\
\text { not seen. }\end{array}$ & $\begin{array}{c}\text { No Fungal } \\
\text { Pathogen Isolated }\end{array}$ \\
\hline 3 & $\begin{array}{c}101 \\
\text { Days }\end{array}$ & $14 / 10 / 2019$ & $\begin{array}{l}28^{0} \mathrm{C} \\
65 \%\end{array}$ & $\begin{array}{c}\text { Microorganisms } \\
\text { Not Seen }\end{array}$ & $\begin{array}{l}\text { No organisms } \\
\text { isolated }\end{array}$ & $\begin{array}{l}\text { Fungal filaments } \\
\text { not seen. }\end{array}$ & $\begin{array}{c}\text { No Fungal } \\
\text { Pathogen Isolated }\end{array}$ \\
\hline 4 & 131 Days & $13 / 11 / 2019$ & $\begin{array}{l}26^{0} \mathrm{C} \\
64 \%\end{array}$ & $\begin{array}{c}\text { Microorganisms } \\
\text { Not Seen }\end{array}$ & $\begin{array}{l}\text { No organisms } \\
\text { isolated }\end{array}$ & $\begin{array}{l}\text { Fungal filaments } \\
\text { not seen. }\end{array}$ & $\begin{array}{c}\text { No Fungal } \\
\text { Pathogen Isolated }\end{array}$ \\
\hline 5 & 164 Days & $16 / 12 / 2019$ & $\begin{array}{l}21^{0} \mathrm{C} \\
56 \%\end{array}$ & $\begin{array}{c}\text { Microorganisms } \\
\text { Not Seen }\end{array}$ & $\begin{array}{l}\text { No organisms } \\
\text { isolated }\end{array}$ & $\begin{array}{l}\text { Fungal filaments } \\
\text { not seen. }\end{array}$ & $\begin{array}{c}\text { No Fungal } \\
\text { Pathogen Isolated }\end{array}$ \\
\hline 6 & 194 Days & $15 / 01 / 2020$ & $\begin{array}{l}19^{\circ} \mathrm{C} \\
57 \%\end{array}$ & $\begin{array}{c}\text { Microorganisms } \\
\text { Not Seen }\end{array}$ & $\begin{array}{l}\text { No organisms } \\
\text { isolated }\end{array}$ & $\begin{array}{l}\text { Fungal filaments } \\
\text { not seen. }\end{array}$ & $\begin{array}{c}\text { No Fungal } \\
\text { Pathogen Isolated }\end{array}$ \\
\hline 7 & 220 Days & $10 / 02 / 2020$ & $\begin{array}{l}240 \mathrm{C} \\
44 \%\end{array}$ & $\begin{array}{c}\text { Microorganisms } \\
\text { Not Seen }\end{array}$ & $\begin{array}{c}\text { No organisms } \\
\text { isolated }\end{array}$ & $\begin{array}{l}\text { Fungal filaments } \\
\text { not seen. }\end{array}$ & $\begin{array}{c}\text { No Fungal } \\
\text { Pathogen Isolated }\end{array}$ \\
\hline
\end{tabular}

\section{Discussion}

Shelf-life is the time period from when the product is produced until the time it is planned to be consumed or used. Several factors are used to determine a product's shelf-life, ranging from organoleptic qualities to microbiological safety. Hence, microbiological study of the Laghusutashekhara Rasa tablets was carried out in present study. Samples were selected randomly to rule out microbiological contamination. Changes in temperature and humidity of environment were observed during study period. Optimum temperature for microbial growth is temperature at which microbe's multiplication depends on types microbes present. The region where the drug was prepared and sample was stored was very proximal to sea coast, so relative humidity $(\mathrm{RH})$ remains high in 
all the seasons of the year. Relative humidity was minimum $44 \%$ \& maximum $86 \%$ of humidity and minimum $19^{\circ} \mathrm{C} \&$ maximum $30^{\circ} \mathrm{C}$ temperature. High $\mathrm{RH}$ can allow the growth of microbes (7), although RH remained variable throughout the study period, air cannot be considered dry at RH exceeding $40 \%$. Wet mount, fungal culture, gram stain and aerobic culture tests were used to study fungal and bacterial contamination in the sample of monthly interval from $5^{\text {th }}$ July, 2019 to $10^{\text {th }}$ February, 2020. During this study period, no any microbe was isolated as a result of aerobic culture and no any fungal pathogen was isolated as a result of fungal culture (as shown in Table 2). Moisture content of drug plays an important role in its long term storage. Moisture content is the main causative factor in drug deterioration; it also acts as an enzymatic activator which slowly decomposes the drug resulting in its degradation (8).

\section{Conclusion}

Microbiological study of the Laghusutashekhara Rasa tablets showed that the quality of tablets was in a standard condition. There were no growth of microorganisms (bacterial or fungal) till seventh (07) month from the date of preparation of drug, which shows its good shelf life at minimum $19^{\circ} \mathrm{C}$ $\&$ maximum $30^{\circ} \mathrm{C}$ temperature and relative humidity was minimum $44 \%$ \& maximum $86 \%$ of Humidity.

Financial support and sponsorship: The study was supported by Institute for Postgraduate Teaching and Research in Ayurveda, Gujarat Ayurved University, Jamnagar, Gujarat, India.

Conflicts of interest: There are no conflicts of interest.

\section{References}

1. Bankoti, K., Rana, M.S. and Bharadwaj, M.K., 2012. Accelerated stability study of herbal capsules. IOSR Journal of Pharmacy, 2(5), pp.1-6.

2. Kommanaboyina, B. and Rhodes, C.T., 1999. Trends in stability testing, with emphasis on stability during distribution and storage. Drug development and industrial pharmacy, 25(7), pp.857-868.

3. Vidyasagar, P.S., 2000. Sharangadhara Samhita with commentaries Adhamalla Dipika \& Kashiram's Gudhartha Deepika, Krishnadas Academy, Varanasi, reprint, Pratham khanda, ch.1, ver 52, 13

4. Vidyasagar, P.S., 2000. Sharangadhara Samhita with commentaries Adhamalla Dipika \& Kashiram's Gudhartha Deepika, Krishnadas Academy, Varanasi, reprint, Pratham khanda, ch.1, ver 52, 13

5. Bruce, J. and Drysdale, E.M., 1994. Transshell transmission. In Microbiology of the avian egg. Springer, Boston, MA, pp. 6391.

6. Alfred E Brown (2001), Benson: Microbiological Application, 8 $8^{\text {th }}$ Edition, the McGraw - Hill Companies, P. 64

7. Sharma, R., Amin, H., Shukla, V.J., Kartar, D., Galib, R., Prajapati, P.K., 2013. Quality control evaluation of Guduchi Satva (solid aqueous extract of Tinosporacordifolia - Willd. Miers). An herbal formulation Int. J. Green Pharm, 7 (3), 258-263.

8. Sharma, V., Sharma, S.K., Cholera, M.S., Pandya, D.H. and Thakar, A., 2019. Stability study of Amalakibhavita nisha used in the management of type 2 diabetes (Madhumeha) - with respect to baseline microbial diagnostic modalities. The Pharma Innovation Journal, 8(6), p. 811-817. 